\title{
The Geopolitical Transformation of the World Order at the Turn of the Twentieth - Twenty-First Centuries: Modern Realities and Prospects
}

\author{
Sergey Alekseevich Butorov ${ }^{1, *}$ Aleksey Sergeevich Butorov ${ }^{2, a}$ Olga Mihailovna \\ Kanygina ${ }^{2, b}$ \\ ${ }^{1}$ Institute of Service Technologies, Russian State University of Tourism and Service, Moscow 141221, Russia \\ ${ }^{2}$ Peoples' Friendship University of Russia, 6 Miklukho-Maklaya Str., Moscow 117198, Russia \\ aE-mail: butorov_as@pfur.ru \\ bE-mail: kanygina-om@rudn.ru \\ *Corresponding author. E-mail: lex1989@yandex.ru
}

\begin{abstract}
The article is devoted to the analysis of the geopolitical transformation of the world order at the turn of the 20th - 21st centuries. The author defines the concept of "geopolitical transformation of the world order", outlines the chronological framework of this process. The article describes the changes and changes in the economy, politics and the spiritual sphere that have occurred in the world community over the past three decades. The author concludes that the geopolitical transformation of the world model is not a one-time act, but a long process. A forecast is given that in the future, mankind is waiting for the next cycle of cardinal transformations, taking into account the development of competition among the world powers.
\end{abstract}

Keywords: geopolitical transformation, world order, system of international relations, new threats and

challenges, international terrorism, confrontation

\section{INTRODUCTION}

At the turn of the 20th - 21st centuries such concepts as "geopolitics", "transformation", and others were introduced into the scientific circulation and socio-political vocabulary of Russia [1].

Several scientific works and textbooks of domestic and foreign researchers on geopolitics were published, which give a deep and comprehensive analysis of this direction of political thought: Gadzhiev K. [2], Dugin A. [3], Pereslegin S. [4], Brzezinski Z. [5], Dergachev V. [6], Kissinger H. [7], Sorokin K. [8], Huntington S. [9].

The Big Russian Encyclopedia gives a multivariate interpretation of the word transformation (from Latin transformatio - transformation, transformation), including international legal content [10]. However, in this universal publication there is no definition of "geopolitical transformation of the world order".

The problems of the geopolitical transformation of the world are reflected in the statements of the Russian political leadership of Russia [11], [12]. Speaking at the plenary meeting of the St. Petersburg International
Economic Forum in June 2016, President of the Russian Federation V.V. Putin drew attention to a serious transformation, profound changes in the world that affect almost all spheres of life [13].

Meanwhile, several foreign social scientists reduce the transformation of the world order to changes in international relations. "The Ukrainian conflict will continue until the world geopolitical transformation ends," writes Ukrainian researcher V. Dergachev [14]. Firstly, V. Dergachev, in our opinion, is clearly exaggerating the scale of the Ukrainian, exclusively domestic conflict, and thereby tries to give it a global, global status. Secondly, the author, analyzing the causes and consequences of the existing Ukrainian crisis, focuses on foreign policy discourse and considers it in the context of the transformation of international relations.

In 2017, the famous British political scientist, professor of the University of Kent R. Sakwa in his book "Russia Against All. The crisis of world order after the Cold War "distinguishes" four world orders "of the last thirty years of human development [15]. The first of them is the world order according to the "Gorbachev model", put forward by the Soviet leader in 
the late $80 \mathrm{~s}$. Its basic basis was to be the concept of a "new political thinking" and the idea of a "common European home". The second is the "model of George W. Bush", which gave its own interpretation of the arrangement of the "European home": "Europe is integral and free." The third "world order" is the "Trump model", according to which the world is characterized by global geopolitical turbulence, chaos, and the West's loss of hegemony. According to the typology of the British political scientist, the fourth order is similar in its essential characteristics to the first: the transformation of all the vectors of world politics, equal economic cooperation, the shift of global political power from West to East. He sees China and Russia as the key actors in world politics [16].

In our opinion, the conditional division of R. Sakwa of the last three decades of the world order into four "models", two of them are controversial. "New political thinking" is the foreign policy concept of the USSR during the perestroika period. Its implementation led to global changes in the world, but they turned out to be beneficial only to Western countries. The Warsaw Pact and the socialist camp were liquidated, while the North Atlantic Alliance expanded its sphere of influence. It is problematic to consider Europe as "integral and free" both in the 90s and today. Moreover, the Old World is not a world community. It should be recognized the objectivity and validity of the third and fourth "world orders" of R. Sakwa - the "Trump model" and the shift of global political power from West to East.

In our opinion, the definition of "geopolitical transformation of the world order" should be understood as transformations that are global in nature and affect the interests of all mankind in all spheres of life - politics, economics, culture, the spiritual world. This is a more complex, universal category compared to a process such as the transformation of the system of international relations. Changes and changes in world foreign policy are dynamic, progressive. The world geopolitical model as a state of external activity, ensuring the inviolability of the goals of the community of states that are necessary for it, vitally important and common to all, is also characterized by changes and transformations. However, they are characterized by scale, cyclicity and multidimensionality. In the context of the restructuring of the world order, it is not the national-state interests of individual countries that clash, but various opposing forces and systems, including all kinds of blocs, alliances of states, which often defend directly opposing positions.

\section{VARIOUS LEVELS OF GEOPOLITICAL TRANSFORMATION}

The question also remains open when the geopolitical transformation of the modern world order began. One can hardly agree with the fact that the beginning of the current century laid the foundation for it. In our opinion, the $90 \mathrm{~s}$ became the starting point of the global restructuring of the world, and it is directly related to the collapse of the former USSR. In 2015, the American magazine National Interest recognized that in the history of mankind there were only five superpowers - the Roman, Mongolian, British empires, the Soviet Union and the United States. According to the publication, the status of a superpower is different from the status of a great empire, since only a superpower has the resources that provide undeniable superiority over all its rivals [17]. Until 1991, the USSR economy was the second largest in the world in terms of gross domestic product (GDP). In the 70s, militarystrategic parity was achieved between the USSR and the USA. The country had significant means of influencing other states and their policies. With the collapse of the USSR, Russia, as its successor, lost the position of a second superpower. According to the ranking of countries by GDP in 2018, Russia ranks thirteenth [18].

With the collapse of the USSR and the world socialist system, interstate relations underwent transformation not only between former members of the socialist community, but also newly formed states in the post-Soviet space. Several countries, yesterday's Warsaw Pact allies, are Russia's geopolitical rivals and are members of the North Atlantic Alliance. There are several regional conflicts on the territory of the former USSR that have remained unresolved since the collapse of the state: Nagorno-Karabakh, Transnistria, Abkhazia, South Ossetia, and eastern regions of Ukraine.

The transformation of the world order had a negative impact on the socio-economic situation of most of the Russian population and the demographic situation in the country. Over the past few years, incomes have declined significantly, and the number of poor is growing. In Russia, there is an acute shortage of labor resources. The standard of living of the population has noticeably decreased in almost all the former Soviet republics. More than 1 million Moldovan citizens left the country in search of a job and a better life [19]. The largest number of foreigners who come to Russia to earn money are citizens of the CIS. In the first half of 2019, 918 thousand people came to Russia from Uzbekistan, 523.9 thousand from Tajikistan, and from Kyrgyzstan 265 thousand, from Ukraine - 164.6 thousand, and also from Kazakhstan - 105.3 thousand people [20].

\section{MODERN CHALLENGES OF GEOPOLITICAL TRANSFORMATION}

The result of the global reconstruction of the world at the turn of the century is international terrorism. Russia was among the first states of the world community to face this one of the most serious threats 
to humanity. The terrorist acts of September 11, 2001 in the United States entailed political, economic, military and humanitarian consequences on a global scale. In October 2001, the United States launched military operations in Afghanistan as part of Operation Enduring Freedom. The International Security Assistance Force in Afghanistan (ISAF) was created, which acted in accordance with the UN Security Council resolution of December 29, 2001. The fight against the terrorist organization Al-Qaeda (banned in Russia - S. B., A. B., O. K), which claimed responsibility for the events of September 11, 2001 in the United States, turned into disastrous consequences not only for the peoples of Central Asia, but and other states. In 2018, researchers at Brown University (USA) conducted a study on the course of the "global war on terror" conducted by the United States and its allies in the North Atlantic Alliance. According to a scientific report, over 17 years of the anti-terrorist operation in Afghanistan, Iraq and Pakistan (excluding Syria and a number of countries) 507 thousand people died. The study also notes that 2.6 million people became refugees from Afghanistan due to hostilities, of which 1.3 million live in Pakistan and 0.9 million in Iran [21].

The fight against international terrorism has served as a pretext for the United States and other Western countries to fight against undesirable regimes. In our deep conviction, the main geopolitical goal for Washington and its NATO allies was to establish their undivided dominance in regions rich in hydrocarbons (Iraq, Libya, etc.). In September 2002, US President George W. Bush, speaking at a session of the UN General Assembly, formulated claims against Iraq, which later became the motives for the US invasion of this country. The key ones were Iraq's accusations of having weapons of mass destruction. He also accused Iraqi President S. Hussein of supporting terrorists in violation of UN Security Council resolution 1373 of September 28, 2001, "On threats to international peace and security from terrorist acts" [22]. The leader of the British Labor Party, J. Corbin, assessing the entry of American troops into Iraq, said that it has led to the spread of terrorism in the Middle East. "This war was an act of military aggression, triggered by a false pretext," the British politician notes. "Instead of ensuring security within the country and abroad, a conflict was launched that created and spread terrorist activity in the entire (Middle East - SB, A.B.) region" [23].

The American invasion of Iraq turned into catastrophic consequences for one of the Middle East's richest hydrocarbons. According to the UN High Commissioner for Refugees, the number of Iraqis who left their country after the US aggression exceeded 2 million people 2007 [24].
According to the Iraqi scenario, the leader of the Libyan Arab Jamahiriya M. Gaddafi was removed from the post of head of state. In March 2011, answering a question from an Italian journalist, is he not afraid to "end up like Saddam Hussein" (S. Hussein was executed by the Supreme Court of Iraq in December 2006 during the period of the country's occupation by American troops - S.B., A. B., O.K.), the head of the Libyan state ruled out such an outcome. At the same time, M. Gaddafi noted that "if they (the West - S.B., A.B., O.K.) will behave with us like in Iraq, Libya will leave the international alliance against terrorism [25].

Under the cover of the invariable thesis of the fight against international terrorism, dictatorial regimes and the protection of human rights, M. Gaddafi was brutally murdered by $\mathrm{Al}$ Qaeda militants with the secret protection of the leading states of the North Atlantic Alliance. The true reason for the physical elimination of the Libyan leader was that the West saw a threat in the encroachment of $M$. Gaddafi on the income of transnational corporations, his global project to irrigate the Libyan desert, the idea of introducing a pan-African currency "gold dinar", nationalization of a third of oil production in Libya, etc. d. These plans deprived the Western monopolies of colossal profits from the supply of food, water, and oil production to the country. Libya, which before the assassination of $\mathrm{M}$. Gaddafi was one of the most prosperous states on the African continent, today has become an arena of civil war and a haven for many thousands of militants of the Islamic State terrorist organization (banned in Russia - S. B., A. B., O.K.).

Meanwhile, over the past few years, Syria has continued to be the forefront in countering international terrorism. The main forces of radical Islamic groups were concentrated on its territory. The Syrian problem, which arose in 2011 and had initially internal causes, was transformed into a global conflict in which the geopolitical interests of several states clashed, including the United States and Russia.

The military intervention of the United States and other Western states in the civil war in Syria with the officially proclaimed goal of the fight against international terrorism began in 2014. However, the military operation conducted by the United States and the international coalition formed under their auspices, uniting about 60 states, is carried out without the consent of the legitimate government of Syria and outside the UN. Russia, unlike the United States and its partners, at the request of the Syrian political leadership since 2015, has been fighting in this country against radical Islamic groups. However, for the Western world, the internal political confrontation in this country and the war against terrorists simultaneously became a struggle against the political leadership of the country, headed by its leader B. Asad. By the end of 
2019, the joint efforts of Russia, the United States and other states in Syria destroyed the main terrorist groups. However, the Syrian conflict remains unresolved. An obstacle to his political decision was the military operation of Turkey under the name "Source of Peace" against the Kurds in northeastern Syria in early October 2019. On October 22, 2019, Russian President Vladimir Putin and Turkish President R. Erdogan in Sochi signed a Memorandum of Understanding between the Russian Federation and the Republic of Turkey, which is designed to be an important step in resolving the Syrian conflict. It is also difficult to predict what the consequences for ending the war will turn out to be the return of American troops to this country at the end of October 2019.

The military confrontation in Syria turned into a real tragedy for its people. According to the Russian military, in August 2018, more than 6.9 million refugees left Syria during the period of hostilities. According to the Office of the United Nations High Commissioner for Refugees, as of March 2020, the number of refugees from Syria exceeds 5.5 million [26].

The political elite of leading Western countries is aware of the degree of danger of new threats and challenges that have arisen in the context of the geopolitical transformation of the world order. Germany considers the fight against international terrorism as one of the priority tasks of the country's domestic and foreign policy.

At the same time, the ruling circles of the United States and its closest allies refuse to acknowledge the growing humanitarian catastrophe caused by armed conflicts in Afghanistan, Iraq, Libya and Syria. The flow of millions of refugees and migrants from war zones and dysfunctional states to Europe was the result of the policies pursued in recent years by the United States and members of the North Atlantic Alliance in relation to these countries. We are deeply convinced that 3 billion euros allocated annually by the European Union (EU) of Turkey in exchange for help with solving the problem of the flow of refugees do not contribute to solving the problem of refugees [27].

The issue of migrants, caused by the geopolitical transformation of the world order, remains one of the most acute in the political discourse of the European Union. According to statistics from Western experts, the total number of migrants and refugees who migrated from zones of international conflict and disadvantaged states to Europe in July 2018 amounted to Immigration to the EU-27 from non-member countries 2.4 million in 2018 [28]. The defeat of the main forces of terrorist groups in Afghanistan, Iraq, Libya and Syria is a great success of the world community over radical Islamists, but this is not the final victory over one of the main threats to humanity.
Do not underestimate the presence of the Chinese factor. China has high-tech manufacturing sectors, and is a world leader in many areas. The amount of accumulated foreign direct investment operating in China is 2.1 trillion. US \$ Foreign capital has laid the foundations for China's new industry. The Russian economy is ten times inferior to the Chinese one. The current economic growth rate of the PRC is 6.4 percent, which is unattainable not only for Russia but also for the development of Europe [29].

One of the most acute and urgent challenges facing Russia is the increase in natural population decline. This issue is on the agenda with the goal of finding ways to overcome these negative trends by modernizing approaches to reduce mortality, unemployment and other negative factors affecting the conditions of the demographic potential among modern young families. According to Tatyana Maleva, director of the Institute for Social Analysis and Forecasting, RANEPA, "Russia cannot return to population growth and this trend for at least 20 years can hardly be influenced [30]

The measures taken by the political leadership of Russia to improve the demographic situation are halfhearted and ineffective. In 2006, the State Program was adopted to facilitate the voluntary resettlement of compatriots living abroad in the Russian Federation [31].

Over the 7 years of the implementation of the State Program, only about 150 Old Believers from South America moved to the territory of the Primorsky Territory and Amur Region, and 2.2 thousand compatriots moved to the territory of the entire Far Eastern Federal District [32].

Another step of the government of the Russian Federation, designed to stimulate the influx of population into the Far East, was to provide Russians with free land. The project is designed to create favorable conditions for citizens of the country so that they express a desire to relocate to the Far Eastern region. According to the Agency for the Development of Human Capital in the Far East, the total number of recipients of land under the program increased by $18 \%$ in 2019 to 76.6 thousand people [33].

However, the state could not offer an attractive perspective for the residents of Central Russia. Free land plots were claimed in the vast majority by the Far East themselves.

\section{CONCLUSION}

We would like to draw some conclusions. The geopolitical transformation of the world order, which began in the $90 \mathrm{~s}$ of the last century, acquired an irreversible process and affected all aspects of the life and work of the world community - economy, politics, 
culture, the spiritual sphere, etc. Its initial frontier was the collapse of the USSR and the world socialist system, which led to dramatic changes in the international arena - the cessation of the Cold War, which lasted for almost half a century, the elimination of the confrontation of two opposing systems, the openness of the world, and humanity's awareness of the global problems of our time, the solution of which is possible only if the efforts of all countries are combined. At the same time, it led to the generation of new threats and challenges, one of which is international terrorism. It poses a special danger to the general world law and order and entails tremendous political, economic and moral losses. The events of the last decade clearly demonstrate that the fight against terrorism can only be waged by the efforts of the entire world community. At the same time, the fight against one of the main threats of the century should include not only military means. The current world order urgently dictates the need to address the economic, social and humanitarian problems that have generated international terrorism

The process of geopolitical transformation of the world order is unsystematic. The world is still unipolar. The USA is the global metropolis - the only superpower that has a dominant influence on the modern world order. Meanwhile, the development of the world community is undergoing qualitative changes. Over the past two decades, China has become one of the leading economies in the world. The leadership of China set a goal to turn the country by 2050 the global powerful power state in the world. It is difficult to predict whether China will succeed in realizing its plans. With a considerable degree of certainty, we can assume that humanity is on the verge of a new cycle of geopolitical transformation of the world order. It seems that it can lead to wider changes in the world community.

\section{References}

[1] Kiselev S.G. Transformations of the world geopolitical model: consequences for Russia // Central Russian Journal of Social Sciences No. 2 (38) 2015. (In Russ).

[2] Gadzhiev K.S. Geopolitics. M.: Publishing house Yurayt, 2011.479 p. (In Russ)

[3] Dugin A. Fundamentals of geopolitics. M.: Publishing house Arktogey - Center, 1999. 928 p. (In Russ).

[4] Pereslegin S. Tutorial of the game on the world chessboard. Publishing House: AST, Terra Fantastica, 2005.624 p. (In Russ).

[5] Brzezinski Z. The Great Chessboard. M., Publishing House: International Relations, 1998. $112 \mathrm{p}$.

[6] Dergachev V. A. Geopolitical theory of large multidimensional spaces: socio-economic aspect // Economic and Innovation Vipusk 40, 2010. pp. 111-126. (In Russ).

[7] Kissinger H. World Order. M .: AST Publishing House, 2019. 554 p. (In Russ).
[8] Sorokin K. Geopolitics of the present and geostrategy of Russia M., Russian Political Encyclopedia, 1996. 167 p. (In Russ).

[9] Huntington S. The Clash of Civilizations. M .: Publishing house AST, 2003. 603 p. (In Russ).

[10] The Great Russian Encyclopedia: in 35 vol. T. 32. M .: Great Russian Encyclopedia, 2016. p. 351. (In Russ).

[11] "It is necessary to find its place in the geopolitical transformation of the world" ria.ru.10.12.2012. Available at: https://ria.ru/20121210/914188138.html (accessed 01.03.2020) (In Russ).

[12] Lavrov S. "World at a Crossroads and the System of International Relations of the Future" // Ministry of Foreign Affairs of the Russian Federation. 09/20/19. Available at: https://www.mid.ru/en/foreign policy/news/-

lasset_publisher/cKNonkJE02Bw/content/id/3792556 (accessed: 01.03.20). (In Russ)

[13] "Putin spoke about the transformation of the world and the global economy" News. 06/17/2016 Available at: https: //www.vesti.ru/videos/show/vid/682973/ (accessed 01.03.2020). (In Russ).

[14] Geopolitician Vladimir Dergachev: "The Ukrainian conflict will continue until the global geopolitical transformation ends" // naked-science.ru 03/31/2015. Available at: https://nakedscience.ru/article/interview/geopolitik-vladimir-dergachev (accessed 01.03.2020). (In Russ)

[15] Sakwa R. Russia Against the Rest. The Post-Cold War Crisis of World Order. Cambridge University Press, 2017. 362 p.

[16] Kazarinova D. B. The Cold War and Peace: "Russia Against All" and the Four World Orders of R. Sakwa. - The policy. Political research. 2018. No. 4. pp. 177-184.

[17] "The National Interest. The 5 Greatest Superpowers of All Time". 05/06/2015 Available at https://nationalinterest.org/feature/the-5-greatest-superpowersall-time-12815 (accessed 01.03.2020). (In Russ).

[18] "Ranking of countries by level of GDP" fincan.ru 06/15/2018 Available at: http://fincan.ru/articles/17_rejting-stran-po-vvp2018 (accessed 01.03.2020). (In Russ).

[19] "Moldova delivers "alien" guest workersprint. Their citizens work in the EU and Russia" Available at: http://www.ng.ru/cis/2020-02-13/5 7794 moldova.html (accessed 01.03.2020). (In Russ)

[20] Starostina Yu. "Uzbekistan became the main official supplier of labor" RBC. 08/16/19. Available at: https: // www.rbc.ru/newspaper/2019/08/19/5d5560979a7947af4fa8a88 3 (accessed 01.03.2020). (In Russ).

[21] Brown University. Human Cost of the Post-9/11 Wars: Lethality and the Need for Transparency. November 2018. Available at: https://watson.brown.edu/costsofwar/files/cow/imce/papers/201 8/Human\%20Costs\%2C\%20Nov\%208\%202018\%20CoW.pdf (accessed 01.03.2020).

[22] George Bush's speech to the UN general assembly // The Guardian 09/12/02 Available at: https://www.theguardian.com/world/2002/sep/12/iraq.usa3 (accessed 01.03.2020)

[23] "Jeremy Corbin: Iraq invasion was a 'catastrophe"// BBC 07/06/16 Available at: https://www.bbc.com/news/uk-politics36724707 (accessed 01.03.2020).

[24] Global Trends: Refugees, Asylum-seekers, Returnees, Internally Displaced and Stateless Persons // UNHCR, the UN Refugee Agency. June 2008. Available at: https://www.unhcr.org/4852366f2.pdf (accessed 01.03.2020).

[25] "Gaddafi threatens the West with an alliance with Al Qaeda" // ria news 03/15/2011 Available at: https://ria.ru/20110315/354126618.html (accessed 01.03.2020). (In Russ). 
[26] Operational portal refugee situation // Available at: https://data2.unhcr.org/en/situations/syria (accessed 01.03.2020).

[27] Artem Filipenok. "The EU will pay Turkey $\$ 3.3$ billion for the maintenance of refugees" // RBC 07.04.16. Available at: https://www.rbc.ru/politics/07/03/2016/56ddb1139a79476da653 0ab0 (accessed 01.03.2020). (In Russ).

[28] Migration and migrant population statistics. Available at: https://ec.europa.eu/eurostat/statistics-

explained/index.php/Migration_and_migrant_population_statisti cs\#Migration_flows:_Immigration_to_the_EU-27_from_nonmember_countries_was_2.4_million_in_2018_- (accessed 01.03.2020).

[29] Mikhail Morozov. "70 years of the PRC: Russia will never catch up with the Chinese" // Free Press. 09/28/19. Available at: https : //svpressa.ru/economy/article/244820/ (accessed 01.03.2020). (In Russ)

[30] The population of Russia has declined again. Available at: https://www.vedomosti.ru/realty/galleries/2020/05/13/830155gidropolisi-nedviga-foto-reya (accessed: 01.03.20). (In Russ).

[31] Decree of the President of the Russian Federation of September 14, 2012 N 1289 (as amended on March 15, 2018) "On the implementation of the State program to facilitate voluntary resettlement to the Russian Federation of Compatriots Living Abroad" Available at: http://www.consultant.ru/document/cons_doc_LAW_135348/9c f95e1cef34d74eca9a5792671e8c9e40db0c88/ (accessed: 01.03.20). (In Russ).

[32] Vasiliev E. "More than 2 thousand Old Believers are ready to come to the Far East" // Ministry of the Russian Federation for the Development of the Far East and the Arctic. 06.09.17. Available at: https://minvr.ru/press-center/news/7709/ (accessed: 01.03.20). (In Russ).

[33] The number of recipients of "Far Eastern hectares" increased by $18 \%$ in 2019 // TACC. 01/13/20. Available at: https://tass.ru/obschestvo/7512093 (accessed: 01.03.20). (In Russ). 